\title{
CITIES AND PERIPHERAL AREAS IN THE ANCIENT WORLD
}

\section{Maria Beatriz Borba Florenzano ${ }^{1}$}

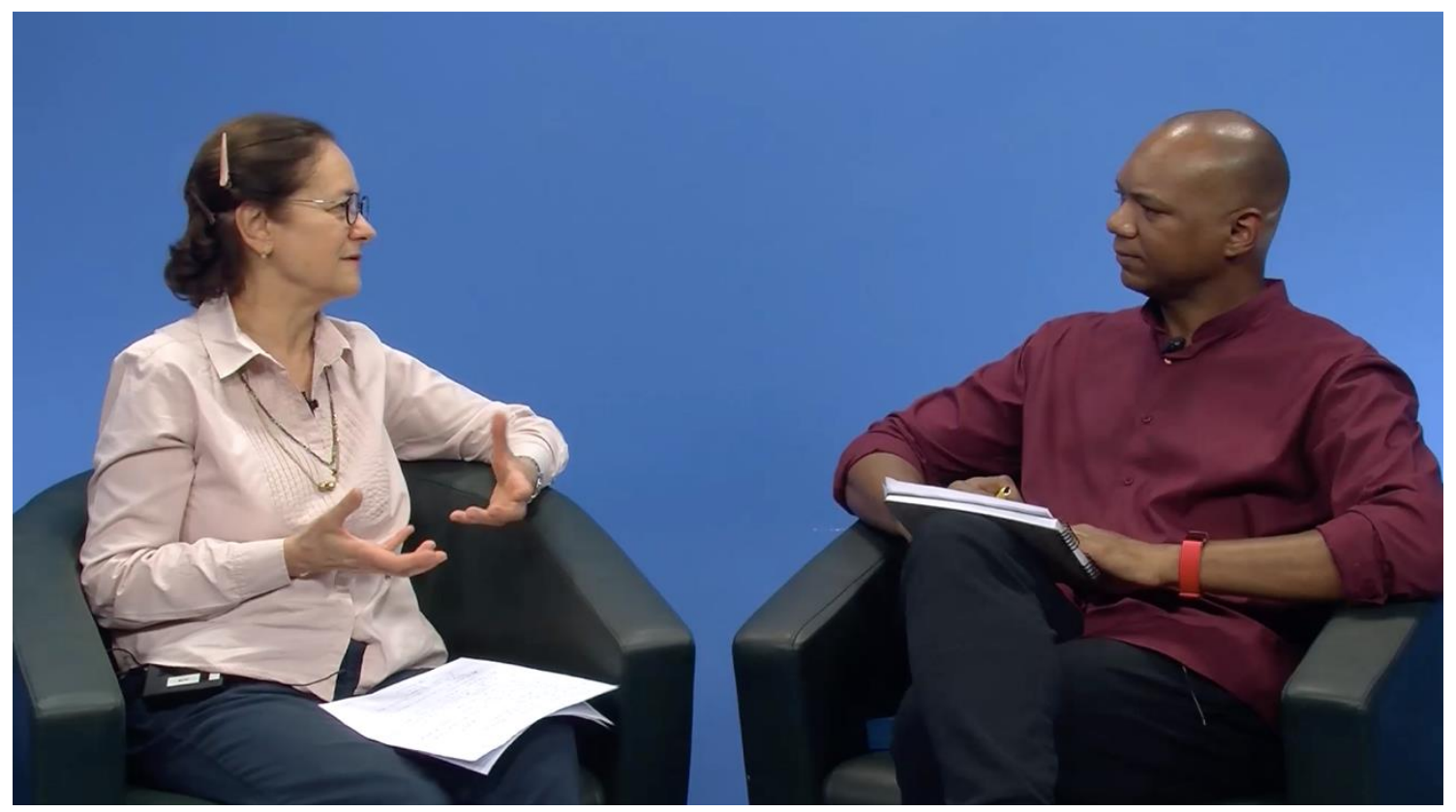

Interview at the UNIFESP studio in September 03, 2018: Professor Maria B. B. Florenzano (USP) and Professor Gilberto da S. Francisco (UNIFESP). ${ }^{2}$

hyperlink to interview https:/ /youtu.be/KzAv8dfqGQc

Herodotus (Gilberto da Silva Francisco): Hello. I am Gilberto da Silva Francisco. I teach Ancient History at the History Department of the School of Philosophy, Linguistics and Human Sciences at the Federal University of São Paulo. The theme of today's interview for Herodotus is the Ancient City. It is a great pleasure for me to interview Professor Maria Beatriz Borba Florenzano, from the Museum of Archaeology and Ethnology of the University of São Paulo (MAE-USP). Professor Florenzano is Full Professor of Archaeology at MAE-USP and the general coordinator of the Laboratory

\footnotetext{
${ }^{1}$ Full Professor - University of São Paulo, São Paulo, Brazil.

E-mail: florenza@usp.br

${ }^{2}$ Interview transcribed by Giulia Cristiano, Jessica Laila, Julio Cesar Teles, Luana Alves, Lucas Knabben, Lucas Lorga, Maria Lidia Motta, Renata Villela, Tairini Aparício de Almeida, Vitória Farias Silva, and proofread by Gilberto da Silva Francisco, Assistant Professor at UNIFESP.
} 
of Studies on the Ancient City (LABECA).

Professor Florenzano, first of all, I'd like to thank you for your presence, which is very important for our journal.

Maria Beatriz Borba Florenzano: I am thankful too for this opportunity, Prof. Francisco.

Herodotus: First of all, can you please tell us about your personal trajectory? You are known for your research work in Brazil on numismatics, that is, on coins. How did the transition between coins and the city take place, as objects of study, in your personal path?

Florenzano: It is true that my entire training has taken place in the field of numismatics, which is the study of these tiny round objects invented by the Greeks. We know this history of the invention and dissemination of coins among the Greeks. Then the Romans adopted them, and until the present -I don't know for how long -, we still have these round metal coins with their small figures on both sides. My entire MSc and PhD training, in addition to many researches, dealt with monetary iconography and monetary circulation.

I did not leave this research field. I continued working with it to this year, 2018, when I recently published an article. It is a chapter on monetary iconography of a book entitled Typoi. ${ }^{3}$ So I did not leave this field. Quite the contrary: nowadays, as I am more towards the end of my career, it is an interest I expect to resume with enthusiasm. But what I have noticed is that, in order to study coins - those really small, tiny objects -, you need to have a certain temper. Many of the students who came to us did not have such a temper with the capacity to dwell with those little pieces and classify a whole bunch of them, which were either similar or distinct from each other. Many of these students even dropped out from their MSc or PhD studies and decided to study other themes.

I had an insight - and nowadays I see that I was not yet realizing it - when I was invited by Professor Francisco Marshall from the Federal University of Rio Grande do Sul, Porto Alegre, to participate in Project Apollonia, in Israel, which you certainly remember. This project was about space organization in Apollonia. I was deeply immersed in it. And it was

\footnotetext{
${ }^{3}$ Maria B. B. Florenzano. In God we trust: gods and god-like entities on ancient Greek coins (Plate XII). In: TYPOI. Greek and Roman coins seen through their images: "noble" issuers, "humble" users? Proceedings of the International Conference Organized by the Belgian and French Schools at Athens, 26-28 September 2012. Liège: Presses Universitaires de Liège.
} 
successful up to a certain point, since this area in Israel is quite unstable for you to be effectively engaged with Brazilian funding. When I joined the expedition in 2000 with FAPESP's ${ }^{4}$ support, we were five people with funds that allowed us to buy many books and participate in a whole month of excavations. We did publish some articles on it, and Professor Marshall even did further work.

At that point I realized that if I assumed a project on the study of space in Ancient Greece I would, perhaps be able to contribute more substantially to the field of Classical Archaeology in our country. You and I were students of Professor Haiganuch Sarian ${ }^{5}$ who was a pioneer in this field and opened many doors for many students. For me, and also for you and many others, she sought to value the field of Classical Archaeology in Brazil. And this was very relevant for me.

So, based on Project Apollonia, I planned to use the study of space in ancient Greece as an umbrella for the work of more students and researchers at all levels. As a matter of fact, space is a very broad subject; and the organization of space among the Greeks, which was precisely our research area, can open different trails into research on themes such as religion, social relations, economy, artisan production and many others. So, based on this, in 2004, we formed a large group of students and professors, and spent a year reading texts about the city, methodologies for approaching cities, and urbanism (without considering urbanism in the entire range of the city). And based on these readings of many authors who wrote about the city and its mechanisms, and its emergence in Antiquity, we draw our first big research project.

It was this movement that allowed us to propose to FAPESP "thematic project" in 2005. It was approved by FAPESP, which continually supported us for 10 years. And for an additional period of two years (we now have a small 24-month project), FAPESP continues to provide us support. This is what allowed us to establish this laboratory. And I think we were successful: the list of researches involved in this lab has 72 or 73 researches in 10 years, including scientific initiation, MSc, $\mathrm{PhD}$ and post-PhD studies. It seems we got it right. We receive messages from the entire country, and also many messages from abroad. I believe it was successful in terms of consolidating more our field in this period. And now you will carry it on. The young students will do the rest.

Herodotus: I believe these introductory remarks presenting the history and

\footnotetext{
${ }^{4}$ The São Paulo Research Foundation.

${ }^{5}$ Haiganuch Sarian, Full Professor at MAE-USP, now retired.
} 
promoting the lab are important, since many people still do not know much about Ancient History projects, and many people have been involved in them. Considering this, can you please further describe the history of the lab, which issues are currently in discussion, and who is working there?

Florenzano: In the case of LABECA, we began this discussion in 2004 by reading fundamental texts on the city. We wrote our first project in 2005 (actually, it was a proposal drafted by me at MAE-USP, to create a themelaboratory). It is the first theme laboratory at MAE-USP, to carry out researches with a specific theme, which is the Ancient City. In our case, we soon realized that it would not be possible for us to work with the Roman city. So, we began only with the Greek city.

This laboratory was created as a space of debates, dialogues and discussions; and it welcomed those individuals who were also working with cities in other areas: for instance, Cibele Aldrovandi worked with Hellenistic cities in India and made her contributions. And also, Professor Kormikiari, ${ }^{6}$ who works with Punic cities, which are zones of contact with the Greeks. We have worked to bring different pieces together and establish a space for dialogues and discussions. The MAE hosted us and I am very proud to say that many other theme labs were created subsequently at MAE in the fields of Brazilian Archaeology, Ethnology and Museology. Today, the research activities at our Museum are based on regimental theme labs with their own individual statutes, their members and so on.

LABECA was established amidst such context, driven by that first project, which set out to pursue a number of research lines: space and society, space and religion, space and politics, space and production, economy, circulation of goods and products, and so on. All this can be seen at LABECA's website, ${ }^{7}$ which we have been able to maintain at great pains. We know that Brazilian public universities are undergoing budgetary cuts, but we have been able so far to maintain a website with our news, products and productions, and our team is cited there.

We worked for a long time with FAPESP scholarship holders, at a time when FAPESP itself was doing better financially. There were times when we had seven FAPESP scholarships for technical training at LABECA for the five initial years. Then we were only able to have two scholarships, and

\footnotetext{
${ }^{6}$ Maria Cristina Nicolau Kormikiari Passos, Assistant Professor at MAE-USP, and coresponsible for the LABECA.

${ }^{7}$ http:/ / labeca.mae.usp.br
} 
nowadays we do not have a single scholarship holder for technical training. On the other hand, we have had scholarship holders of the University under the student permanence program. These are undergraduate scholarship students participating of the University of São Paulo's Unified Scholarships Program. We also have scientific initiation students funded by PIBIC $^{8}$ and other MSc and PhD scholarship holders who support LABECA.

We work in a small space of approximately fifteen square meters, which is maintained with FAPESP resources, and I have a productivity scholarship by CNPq; I am also able to use CNPq funds to keep our library alive and focused on the themes we are studying there. In these ten years, we have already hosted one national symposium and one international symposium. We are now organizing a second international symposium, which will be held in April 2019. And we have held a number of internal workshops, with students, professors not only from USP but also invited from other Universities. Our intention is always to promote debate and to grow in the production of knowledge.

This is how we are moving forward, as we pursue the aim of focusing on one theme. I believe dispersion does not produce new knowledge; it does not lead to innovation. However, one thing I have learned at LABECA is that working as a team is quite difficult. It is much easier to remain in your own office, reading and writing in order to teach your lessons or produce your own articles. Working as a team is hard indeed, but the results of such work are very rewarding.

Professor Elaine ${ }^{9}$, who is participating in the lab, also organized an exhibit that allowed us to grow a lot. We created digital models of "built environments" and worked also a bit with scientific dissemination, which involved a great deal in terms of research. And one can only do these things with the support of a team. This is how LABECA has been working. We published two books and there is another one, which is about to be published by Intermeios, where we have a chapter briefly describing LABECA's history. We have also published a Proceedings of a Congress as our third book (we call them book one, book two and book three). So the fourth book is the one in editing stage now, and until the end of this year we will be producing our fifth book. We have its articles already, which I am formatting at this moment, and which also bring up a bit more about

\footnotetext{
${ }^{8}$ Institutional Program of Scientific Initiation Scholarships, funded by the National Council for Scientific and Technological Development (CNPq).

${ }^{9}$ Elaine Farias Veloso Hirata, Associate Professor at MAE-USP, and co-responsible for the LABECA.
} 
the lab.

Herodotus: Now thinking about the theme of the ancient city: can you please speak more about the existing studies on it? Which are the perspectives and contributions of History and Archaeology in relation to this theme?

Florenzano: As I see it, when we started studying the history of the Greek city, we were in an almost traditional position, since we were focusing on the city, i.e., the polis and its urbanistic aspects. Our most important references from the standpoint of urbanism were Roland Martin, a great French archaeologist who studied Greek urbanism in a quite systematic way; and Amos Rapoport, who is a great North American architect with a very didactic and widely translated work, which is useful for us. Rapoport writes about the issue of the built environment and, in essence, about the city. We learned quite a lot with these readings, but then one begins to dig further into archaeology and material data. I believe that in its four or five initial years, LABECA was strongly focused on the built environment within the city.

We then began noticing that the City-State as a concept was not in line with the material documents; this is the most interesting issue. After ten years working with this theme, I can tell you that the literary data guided our studies on Antiquity in a very insistent and incisive way. And we harnessed the elements from these textual documents that satisfied the curiosity and the needs of each moment in time. So, in the Renaissance period, Aristotle and Plato were read among the available works (the text on the "Constitution of the Athenians" was only found in the $19^{\text {th }}$ century), but that was what one could find in the Renaissance. And what was taking place in Europe back then? The emergence of National States. So, did it not express a need to seek support in the ancients, in terms of better knowledge regarding States?

And based on this, what was the focus? Politics. Why was the polis translated as City-State? Because our word politics comes from polis, doesn't it? I believe that up to the 1940s and 1950s, the textual documents were appreciated in this aspect. If we take the Copenhagen Polis Center (thank goodness it is Copenhagen Polis Center, and not "Copenhagen CityState Center"), their focus was the City-State and, up to the present day, many translations take the City-States for granted and assume that nobody will ever change it. But for us, this is a bias focused above all on urban life and political life. In the 19th century, it was the same thing. In other words, the new imperial States, England, democracy, that's what is seen. So, these biases were the emphasized ones. 
Nowadays, first of all, we have Archaeology giving us a special glimmer. And, second, our issue is not the State, but the fact that so many people are moving around, isn't it? Either in Europe or here in Brazil, we turn on the television and see those boats continually arriving and sailing across the Mediterranean Sea; and now this crisis in Venezuela, with people leaving the country to migrate elsewhere; and just think about how many other large-scale population movements have taken place in the course of our history. So, what do we see nowadays? The Greeks are moving back and forth, and Greece - not the Greece of the cities, but the Greece of networks. And I think that contribution of archaeology to this phenomenon was fundamental.

For these reasons, the research I would like to carry out - the one I gave to Guilherme Moerbeck - is precisely on how the history of Greece moved from a history of the city towards the history of the Mediterranean. We will read again the texts: did Plato not say who were the Greeks? They were like toads and ants by a lagoon. This means that we ignored this side of the Greeks and appreciated the value of the city, i.e., the city and the State, by calling those nuclei City-States. So, I believe Archaeology will drive this movement. There is the great Cambridge School, with Snodgrass advising so many students that include very competent archaeologists and historians such as Jonathan Hall, Catherine Morgan, Carla Antonaccio, and Susan Alcock.

I believe it was Archaeology that started this trend from the end of World War II. Since monographical excavations are expensive and their results sometimes do not pay the costs, starting in the 1940's or 1950 's, archaeological surveys, which are much cheaper, began taking place in a more systematic way. We see the mobility that the Greeks had, and how the frontiers were frons, as the Latins used to say. And what are these frons? A fron is that area where you want to get to, and such frons (which is a part of the word frontier) was not always the wall of a city, i.e., a fortified nucleus. That was not the frontier. In the $19^{\text {th }}$ century, people sought to grasp each city with its walls, but that was not the frontier of a polis. Such frontier was way beyond its walls; it could either expand or shrink, and this is what drove the Greeks to interact with so many people who were not Greek. This is truly fascinating!

I have great respect for Irad Malkin, a leading Israeli archaeologist who systematized the study of networks. As we can see through his work, Athens was not only the city of Athens; it was not only the Empire that dominated other populations for a certain period of time. The linkages and affiliations among different polis show that there were many overlapping networks: there were the Dorians, the Achaeans, and then women, religion, 
and so on. Such networks were continually overlapping and flowing throughout the Greek world. But then why do we only talk about the Greeks, and not about so many other people who were in contact with them? I do think about this. There were the Phoenicians - a truly amazing population, which gave birth to an extraordinary civilization - and other groups who entered into contact with the Greeks. I say that the Greeks invented coins, but as a matter of fact, coins are a heritage from the Middle East, which emerged in that region of Anatolia and Mesopotamia. I mean the weight and measure' system as a whole, and not specifically the monetary system.

So why do we talk about the Greeks nowadays? I believe we do it because they had the creativity to absorb many things from the other populations and received their influences without losing sight from their own features. As Herodotus - the same Herodotus that gives a name to this journal wrote, "language, religion and walk of life". It is just a pleasure to study these things. I really must be thankful for having this chance. The University of São Paulo gave me this opportunity, and FAPESP contributed to it. Otherwise, who else would pay me a salary to study these things? Just think about it. With so many problems we are now facing. But I believe that a great contribution to the human spirit and to Brazil is involved in this work.

Herodotus: There are actually some issues here, which we will be discussing, on how to think about our city based on these ancient cities and their references.

Florenzano: We make digital models of ancient poleis and of their features, and many of these models are available at our website. Some of them even have a game-format, with a Greek port, and then a model of a sanctuary, and then a Greek city, and a Greek house. When we see small children looking at them and comparing them, we see we are making a contribution and showing that, based on the study of others, you can construct your own identity. I also have this impression about the Greeks themselves: they consolidated their own identity by observing the others.

Being in a museum such as ours is an advantage. Children get crazy at what they see there: not only the digital models, but in the exhibit set up by Professor Elaine, also a physical model they can touch, feel and look at. They can compare a Greek house from 2000 years ago with their own homes. The pathways within the city, its dwellings and so on. The more you get to see and learn about it, the more you construct your own identity and realize the way you act. 
Learning about the Greeks is not a case of saying, "we're just like them". We are not just like them, and this is the point. "Oh, they also had small round metal coins"; but coins for them had many other meanings, and it is a mistake for us to ascribe to ancient Greek coins, and even Roman coins, the meaning that coins have for us in our impersonal market economy. And so on. So, the study of the others - being able to compare and see the differences - is what makes us citizens, is what makes us be who we are, as we construct our identity.

Herodotus: When you talk about these changes in terms of understanding the city, I always remember that when we study the ancient world, above all Greece, some cities come to our mind that are usually showcased as if they represented Greece in its entirety. So, we have Athens and the entire current debate, which deconstructs this athenocentric perspective. Can you please tell us more about this diversity-process in relation to the city in the ancient world?

Florenzano: This is a topos that never goes away. Athens and Sparta are mentioned in the very first place. Athens and Sparta, and then often we see Thebes, and then Corinth. In any guidebook, if we want to talk about the Greek theater that is enshrined in the textual sources, we will have to talk about Thebes. People want to talk about Troy, because we read the texts that mention the Trojan War, and all that thing. Homer, Hesiod and Herodotus himself. Well, Herodotus is the one known as the great one, the one who opens many doors to other civilizations. But if you take a fundamental text that has remained to this day as a main text on the History of Greece, namely Thucydides' text, you will find specially Sparta and Athens, despite the fact that he speaks about many other cities.

In any guidebook or manual - above all in Portuguese -, this is the case. I believe that European school books are already taking a step away from this pattern, but the Brazilian books are not. It is just unbearable, the same old story of Athens and Sparta, and so on. This is a very important point for reflection: I think archaeology is also allowing us to deconstruct things and reach new perspectives, with a reinterpretation of the available texts and the ability to find elements in the texts, including things we did not want to see before. I think archaeology has a really great contribution to make in this sense.

Well, first of all, why Athens? Why Athens? This is something I frequently think about. Because one could say, "oh, athenocentrism belongs to the $19^{\text {th }}$ century". But it does not. It is not something from the $19^{\text {th }}$ century, since it already existed before that. 
Herodotus: Since Antiquity itself.

Florenzano: It dates back to Antiquity itself. I have a quite particular view of it, even though I have not yet written about it, since this is not my area. But take a look at Canfora's work, ${ }^{10}$ you and Fabio, since you also wrote a text on athenocentrism. ${ }^{11}$ My particular idea is that Athenians created a reflection on themselves. And I think this is what attracted the Romans, i.e., this reflection they produced on their city, on their way of life, made way for others to think about it. For instance, Aristotle was not an Athenian citizen. Athens was a special, exceptional city, which made way for a reflection by Athenians on themselves. And this is what stirred so much interest. Hadrian was "stoked" on Athens, and Cicero moved into the city.

I sometimes even think this is what perhaps led them to preserve the local texts, which were conserved in much better conditions than other texts produced in Asia Minor, and even in the West. For instance, Timaeus' work has practically disappeared and was preserved mainly in fragments in Polybius. With what criteria the ancients made their choice of texts? Just to mention an example: what about the constitutions written by Aristotles's school? It seems that his school was responsible for many constitutions. The Constitution of Athens was only to be found in the 19th century. But what about the other ones? They are now fragments in many other texts. The ancients themselves preserved the works from Athens. This does make us think. I believe Canfora answers this question in a way by speaking a lot about democracy. It seems to me this is a very interesting point for reflection, and scholars must face it straight. It is not enough to deconstruct; there is something there, there is something there indeed.

Herodotus: Thinking about this too, can you please speak more about the diversity I have been able to see in many LABECA communications and lab presentations, i.e., this big repertoire of cities?

Florenzano: Well, for instance, it is repeatedly said: "oh, Greece invented democracy". Did Greece as a whole invented democracy? If we take a closer look, we find many examples of other important cities in the Greek network. For instance, Taranto, Locri, Naples itself, and Reggio in southern Italy; Crotone as an extremely important city; Eleia, the birthplace of great philosophers - and Crotone was also the home of Pythagoras; and Thurii. In Sicily, Syracuse was almost as large as Athens, and at some moments it was even more powerful than Athens. Syracusans sailed up the Adriatic

\footnotetext{
${ }^{10}$ Luciano Canfora. Il mondo di Atene. Rome; Bari: Editori Laterza, 2012.

${ }^{11}$ Gilberto da S. Francisco; Fábio A. Morales. 'Desvelando o Atenocentrismo.' Revista de Culta e Extensão USP, vol. 14, p. 67-79.
} 
conquering cities, and it was as powerful as Corinth, which sunk. Think about Argos, which is so rarely mentioned except for tragedies. In Sicily you have Agrigento and Selinunte, two huge cities. Selinunte was huge with its planted fields and a gigantic khora, and it maintained permanent contact with the Phoenicians. And there were cities to the north too. What about Marseille? Does anyone remember that Marseille was founded by the Greeks? Now who will remember that?

So, these cities did play an essential role. Not to mention the cities on the Black Sea: Istria, Olbia, Irakleia and Apollonia. And Miletus: what do people say about Miletus? There is only an urban plan since Von Gerkan went there in 1924 and made his urbanistic study of the city. And that urban plan is Roman, not Greek. But Miletus was a local power. According to Herodotus, it had a pearl necklace on the Black Sea comprising many colonies, and each colony is taken here as a pearl. These were powerful cities. Phocaea to the north, which founded Marseille, and Eleia on the other side of the Mediterranean. Now, who remembers these cities? And were all of them democratic? We know that the answer is no. Tyranny, democracy and oligarchy took their shifts in power.

There were a large number of cities. Many of them are being excavated nowadays. Thasos, for instance, was intensely excavated by the French School. Many things are now known about Thasos and the entire area dominated by it in the pereia, outside the island, on the northern Chalcidian coast. Olynthus, for instance. This area is known because many of its houses were excavated. But perhaps it was not as important as Thasos, Samos or Phocaea. And so many others; Miletus, and many others. Ephesus, where the first coins came from. Now (to advocate on our behalf), I think that the Greek world is a really vast world. It is not only really vast, but it also popped up along the entire Mediterranean coast.

For instance, think about Naucratis in Egypt - a colony founded since the $8^{\text {th }}$ century with the pharaoh's permission. I think it were twelve Greek cities participating in its founding, which then maintained the city as a neutral emporium right there at the pharaoh's delta. Or think about Cyrene in North Africa, which I believe is currently in Libya. Approximately in the $8^{\text {th }}$ century, Greeks founded Cyrene and immediately founded four other cities around it. These were all Greek cities that shared a space with the Carthaginians from today's Tunisia. So that was a sea the Greeks shared with the Phoenicians in a balanced way; sometimes they would quarrel and, sometimes, they would be together, because they were coexisting. A proof of that is the fact that the Phoenicians were the ones who created the alphabet. 
And why have the Phoenicians not received the same attention as the Greeks? You know Jonathan Hall's thesis, right? It is because European prejudice did not allow that to happen. Because the Phoenicians were from the Middle East; and they were mixed, as a rule, with the Jews - and there was that European prejudice against them. This is Jonathan Hall's thesis. As Alfonso Mele (a great researcher who writes in Italian, so some people do not read him) shows in his book Prexis ed emporie, in those $8^{\text {th }}$ century boats there were Aeginetans, Chalcidians with the Phoenicians. It was a network-world. I think network-theory accounts for their reality better than the City-State concept. It does account for many things, and I think the contribution of Archaeology in this regard is essential.

Herodotus: Regarding the complexity of these concepts, we often see that the usual notions do not correspond to the complexity of these advances you mentioned. I remember Kostas Vlassopoulos saying that the polis - a concept generally used in reference to the Greek world in a uniform way is not enough. Vlassopoulos then resorts to this network-logic towards an understanding of certain periods of the Greek world as a peripheral area in a process that had been developed by the Persians. Can you please speak about these concepts? The polis, City-States and, above all, "colonies", i.e., the notion of peripheral areas; this notion of periphery is so important here, since, in our case, we also have this issue of an academia organized in a peripheral region.

Florenzano: Well, I think we already talked a good deal about City-States. Regarding the issue of colonies, this concept of colony had a Latin origin concerning colonies founded by the Romans - which, in modern historiography, were characterized as a form of European domination over other territories. The African colonies and the American colonies, and also in Asia (India in the case of the British Empire, and so on). As you may remember, in 1998, Robin Osborn raised the claim that the concept of "colony" is mistaken and we should, therefore, use other notions instead of the colony-concept. The French were left in distress and immediately began thinking with notions such as "diaspora" or "expansion", but still and always thinking about a Greek basis for diasporas or expansion in the Mediterranean.

There was a recent discussion about this issue of the Greeks in the Adriatic, and the term "colony" has been challenged. People reached the conclusion that if you use the term "colony", you are in fact resorting to Immanuel Wallerstein's idea of a center and a periphery; you would then have a center radiating outwardly. The theory of networks, in turn, proposes another perspective that identifies several knots or nuclei radiating from other nuclei creating a huge area of overlapping networks, i.e., of 
overlapping contact and mobility lines.

In the case of the history of the Persians, for instance, - and this is something that almost knocked me out - at the time when I taught at Brown University (I think it was in 1994), Ross Holloway came to me and said, "look, have you not noticed that those ceremonies, those processions depicted on Persian friezes, are just like the procession we see on the Parthenon's frieze?" And I said, "oh my God, that might just be the case". So, according to him, many Greek craftsmen were hired by Persians.

But then why does chapter three of Herodotus contain a famous discussion at the Persian court about the best government? Why? Because the Persians were present there with their own government, leading Athenians to reflect on it, and then there was a discussion later resumed by Polybius, right? Thus, the Persians were part of that network Vlassopoulos is now talking about. But I don't know whether the Persians were the center of such network. I really don't know. Nowadays we are not talking about the Persians, or are we? Here in Brazil, are we talking about the Persians? And this is the history we have to face with an open heart.

Thinking about it, the notion of "colony" leads to a complicated issue, since we already assume the existence of a subordinate party. And when we talk about the Greeks, if we dilute this issue, what word should we then use? Will "diaspora" do? No, it will not. What about "expansion"? It doesn't serve us well either. Dominance? Empire? What word could we use from our vocabulary? And this is what Emanuele Greco ${ }^{12}$ made me think when he came to the Conference we organized in 2013. He said, 'so, people won't use the word "colony"? For us Italians, it doesn't matter. There are expressions we must use, but for us, it doesn't make a difference. If this is really bothering you, then you can use a Greek expression'.

And at LABECA, we began using the Greek term apoikism. We use the word apoikia and avoid the word "colony". We avoid the expression "CityState" and we use apoikia, since this is the Greek term. And we are using the expression apoikism, since this is a term derived from the Greek apoikia. So, as I said, from which perspective will you approach the Greeks in the Adriatic? You must have a point of support and reference. Will the notions of center and periphery be useful in some occasions? Yes, they will, but now they must be adapted.

The latest issue of the Cadernos do LEPAARQ, issue 29, has a dossier on Greek colonization. It contains an article written by Airton Pollini that also

12 Emanuele Greco, Full Professor, University of Naples "L'Orientale", and former Director of the Italian Archaeological School of Athens. 
opens the doors to our reflection. In her livre docência study, Professor Elaine also dealt with the issue of this term: what will we use? Should we use the term "colonization" or not? And we keep swinging between "so let's use it" and "let's not use it anymore". At LABECA, we somehow got tired of that, because we end up wasting time with a theoretical issue. Well, in fact, it is not even a theoretical issue; instead, it is a nomenclature-issue, and we know we could use the word "colonization" while explaining some things. But then we bump into each other in issues linked to guidebooks. If you write "colonization" in a guidebook, you will have $5^{\text {th }}$-grade teachers understanding it as colonization in the same way as the colonization of Brazil by Portugal.

It is so that in our texts, translations and projects, we have been using the words apoikism and apoikia. We do use the word polis and, sometimes, 'city', but we are not using the expression "City-State". This is a debate, and I am open to debating. The Cadernos do LEPAARQ issue I just mentioned also brings a text on Syracuse written by me. When I proposed to publish this text, I was criticized for not using the words "colonization" and "colony". And I said, "look, this is the way it is, I believe I am making a contribution to the field of classical studies in Brazil. So, now let's discuss it".

We have a glossary at LABECA, and we actually appropriated the word apoikia into the Portuguese vocabulary. Was not also the word "cleruquia" ["cleruchy"] successfully added to Portuguese? The same with "cleruquia", with q. These were the Athenian Empire's colonies, the military colonies of kleros and oikos. So why shouldn't one use the word apoikia? But now we have the new spelling of the Portuguese language, in which $q$ became $k$. So, I said, I will be using apoikia in Portuguese, and apoikias as its plural form. I don't know if you are aware of it, but the plural form of polis in Portuguese dictionaries is polis. People have that voluptuousness in relation to vocabulary, and they like saying poleis, because it sounds beautiful, and it seems that they're more learned and erudite. I let my students do it. They like doing it in their dissertations and theses, and they write polis and poleis. LABECA's glossary has room for that.

Herodotus: I find this interesting, since it already and somehow develops the issue of what is it to think about the ancient city in Brazil. Considering what we are facing here in Brazil.

Florenzano: It is hard, isn't it? So hard. I remember when I was an MSc student working with coins; I think it was a 1911 publication, and later 
Professor Ulpiano ${ }^{13}$ bought to the Museum a 1976 book, which was the latest one back then, published by Colin M. Kraay. I later discovered other guidebooks on numismatics from the 19th century, and all this provided the basis for my master's degree. I had neither a scholarship, nor money for anything. I think our main difficulty in terms of studying the Greek city, in the case of classical studies, is that we can also include a discussion on the "classics" and "civilization", since all this is being discussed. But when it comes to studying, for instance, the Greeks and Romans, the biggest difficulty is money, that is, research funds. It is hard to obtain funds.

In some stages, we greatly benefited from FAPESP funds, and FAPESP was always open to support us. But this field involves the knowledge of languages, since it is necessary to know Greek and Latin. And so, training in this field takes much longer than, for instance, the training of an archaeologist who will be working with Brazilian Archaeology. It takes a longer period of training with the study of languages, and the knowledge of sources and of a bibliographical corpus dating back to Renaissance itself, depending on the theme you will be working with.

In Human Sciences, differently from the Exact Sciences, a student's dialogue with those who preceded him or her must be permanent. It must be a permanent feature. One cannot write about democracy and ignore other authors. One cannot write about the Greek city and ignore Fustel de Coulanges, who wrote about it in the $19^{\text {th }}$ century. It simply cannot be done. It is a good, but complicated reading. One cannot speak about the Greek city and ignore all those texts written by Burckhardt, right? And there are older texts, for instance Marx, which refer to many currents of thought linked to Antiquity and can't be ignored. Otherwise, one would not be writing about the history of the past. Thus, in addition to a heavy bibliography, to the sources and the study of languages, there is a lack of funds.

The North Americans, for instance, have lots of research resources. Any scientific initiation student willing to study can find a scholarship and fly to Greece and Rome. They count on schools - the American School of Rome, and of Athens - that provide them support and accommodations, and take the students to the excavation sites, so they may learn. Myself, for instance: where did I go in order to receive my excavation training? I went to Mexico and to the Amazon. It was not then possible for me to go excavating in Europe and learn it there. Nowadays, this can be more easily done.

${ }^{13}$ Ulpiano Toledo Bezerra de Meneses, Full Professor at FFLCH-USP, now retired.

Heródoto, Unifesp, Guarulhos, v.4, n.1 - 2019.1. p. 26-44

DOI: https://doi.org/10.34024/herodoto.2019.v4.10083 
First of all, it is easier because we have the internet and can download tons of pdf files. Back then, in the 1970's there was only one xerox machine at USP. We therefore depended on those who could make photocopies copies abroad and send them to us. I remember that back in 1982, I spent four months in Belgium as part of my PhD-trajectory, and I brought back 40 kilos of photocopies to use them in my research after returning to Brazil. And I did the copies myself. Things have really changed.

Nowadays, I believe our most frequent difficulty is the lack of funds. I mean travelling funds, since one cannot simply land on a country and begin excavating. One must often buy authorizations or become a member of a research group abroad. And in order to be a member, for instance, in Greece, one must be linked to a school. Professor Francisco, you are now a member of a school abroad, and you know the process you had to go through in order to get there. The school welcomes you, but it does not give you any funds, so you have to ask for such funds back home, and the maximum they will give you is funds for your accommodation. Even at the French School, publishing is so difficult now. They are also out of money. One must find the place to be inserted. After all, this was the reason why our project in Israel did not went forward; we needed more funds to maintain an excavation in Israel, and the Americans went to Apollonia and offered more. They entered Apollonia, and we did not. This is a problem.

Now, a thing that won't let us lose heart is the fact that many excavations have taken place since the $19^{\text {th }}$ century, and so many collected materials have been kept with their source documents in the magazines and storage rooms of many European museums and Institutions. In my case, since I study coins, they are maintained in the cabinets des médailles, which are numismatic storage rooms; in the case of Italy, for instance, they are found at the regional superintendencies of archaeology, as they call them there. There are a lot of materials to be published, which have not yet been studied. For instance, if you are interested in Mesopotamian archaeology, the Louvre Museum has over one hundred thousand tablets still unread and unpublished.

So, the materials do exist. The material data, i.e., primary sources are out there. And we depend on negotiations in order to study. I believe the funds are scarce here, but they are also scarce in Europe for this type of study. And some pathways can be truly complex and bureaucratic. But there is a lot we can do and achieve. I believe this field still has so much to be done, and there are many catalogues.

For instance, I will be studying Calabria under LABECA's new project. There are many basic materials published in the form of catalogues, which 
have never been deeply studied. Many surveys have been published, but there are no interpretations on them to this day. The data is published and something is suggested, and that's it. This is a contemporary archaeological trend: studying the catalogues, studying them anew and checking the findings, bearing in mind today's mobility.

Herodotus: It seems that the current crisis also forces us to think more about what is already excavated and what has been already published and developed.

Florenzano: Definitely, yes. I do not discourage my students, as I do believe there is a lot to be done. An advantage of being in the "periphery" or "colony", as we are, is the fact that we do not need to join any "clique". I can criticize an author and praise someone else without hurting them. I can take the best from each one and add it up to create new things. I think we often do this at our lab: we consider what the British are saying, what the many Italian cliques are saying, and we are able to create something new using the material they provide us. I think this is interesting, and this dialogue has proved it. I have heard from great specialists, things like "you know, I hadn't thought about that. But this author you mentioned is a fool, I can't stand her!". But here in Brazil, I can profit from everyone's interpretation... I believe we have some advantages in this regard.

Herodotus: Professor Florenzano, to conclude our interview, I would like to ask you about two elements linked to the results of the lab and to all these reflections in the course of the recent years, reaching beyond the academic setting. The first of these elements is the exhibit held by MAE until recently, entitled "The polis: living in the Greek city". Since it is already over, I think it is even possible to reflect on what this exhibit has attained and its reception. And also, in connection with its results from the educational perspective beyond the academic world.

Florenzano: The fact that we are based at the Museum opened this possibility of organizing a high-level scientific exhibit, since it allowed us to put up a website aimed at the diffusion of different perspectives. As I said, we have many digital models. We also produced a 26-minute DVD on Syracuse, which includes a booklet for teachers. ${ }^{14}$ In addition to the digital models of specific spaces (such as the harbor, the house, the city and the sanctuary), we also have two short movies produced in 2007, when we went to Sicily. They are freely available, and anyone can visit our website and watch them, or play with the videogame, which is the harbor. These

${ }^{14}$ Silvio L. Cordeiro. 'Siracusa - Cidade Antiga.' Revista do Museu de Arqueologia e Etnologia da USP, Suplemento 12, p. 79-80, 2011. 
are LABECA products. ${ }^{15}$

In addition to this learning material we produced - the movie on Syracuse with the booklet for teachers -, there is another booklet we produced on the ancient city with images. It is a type of illustrated glossary. We hired a drawer who created many spaces of a Greek city, including some parts that are not located inside the urban center, but are outside it. And with these drawings, we explained each space. The booklet is also available at LABECA's website.

The exhibit was very rewarding, because it was intensely visited by school groups and the educators of the Museum made a special program to receive high-school teachers and provided special training with the learning materials produced by Professor Elaine. She wrote a text - I am not sure whether it was made available at the website - with images, aimed at teachers. And based on these training activities, the teachers returned to their classrooms to explain things to their students, and later the students would come and visit the exhibit. We made photos and realized how the children / students (from early age up to high school) were very enthusiastic about the visit, and how they enjoyed this exhibit. At the exhibit, one of the digital models was available so that the visitors could interact with it. This was a very interesting experience. I also went there with some undergraduate students from an elective discipline, the one you took some time ago.

Herodotus: History and Archaeology of Classical and Hellenistic Greece.

Florenzano: Yes. We still have this same discipline, but I am changing it every year. In the first semester of 2017, I told the students, "you will take the entire morning to go visit the exhibit". I had given them the texts to be read, then they visited the exhibit and presented a critical evaluation considering what was missing, and what was there. Most of them were enthusiastic about it, so the university' students themselves were showing the importance of that type of exhibit as a learning-experience for them. I felt really glad about it, and I thought Professor Elaine deserved to be congratulated for the work, since she spent an entire semester planning the exhibit along with the other educators, museologists, and the Museum then supported this initiative.

I am sorry that as a result of the lack of funds, our database Nausitoo named after Nausithous, an archetypical founder of cities in Greek mythology - is not currently available. We have been receiving many

${ }^{15}$ http:/ / labeca.mae.usp.br/pt-br/professores/ 
requests of images and of access to Nausitoo. But so far I have not been able to reply all of them. I can't do it all alone, and the database needs to be updated in order to be made available to the general public. But I am receiving requests from professors from the University of Amazonas and from colleagues from São Luís do Maranhão and Rio de Janeiro. Everyone is requesting images and access to the database. We have seen requests even from abroad. And why? Because all those contents are gathered into this one database.

Even in Italy, it is not so easy to find so many things gathered at the same place. You find sometimes access to things via the Internet, but the quality of images is not so good, and we can offer images with a resolution of 300 dpi. Some photos were taken by ourselves, and other photos were scanned by us, and we always included the lab's watermark, thinking about copy rights and all that hassle. But one thing we requested in this new FAPESP project, above all, in order to develop our database, is a consultancy on information technology, so we may update this part of our diffusion-work.

As you can see, our lab is working in several levels. We have our scientific diffusion activities and are now aiming at our fifth book. That is a good pace, isn't it? I believe five books in ten years are quite good. And we have $70+$ research projects and these typical products of our work. We also translated many texts and made book chapters and our own artisan translations available on the website, which serve as learning materials. We also have an access-map, which allows us to know who is accessing our website and from which location. Sometimes I take a look at it and say, "wow, someone in South Africa has visited our website, or someone from Australia".

There are somethings we could develop further if we had more funds and possibilities in terms of getting new students involved with scholarships. But I think we have done quite a lot anyway. We have been able to accomplish many things.

Herodotus: Yes, certainly! Thank you very much, Professor Florenzano. I really appreciate your presence with us.

Florenzano: And I thank you too. I like these things, and I believe it is important for our field of Classical Archaeology and the Greek world. It is very important indeed, and it is an opportunity for us.

Heródoto: Thank you. With that, we end today's conversation. 